\title{
ALt-J \\ ASSOCIATION FOR LEARNING TECHNOLOGY JOURNAL
}

An international journal devoted to research and good practice in the development and use of learning technologies within higher education

\section{Editor}

David Squires, School of Education, King's College, University of London, Waterloo Road, London SEl 8WA. Phone: 0207848 3107. Fax: 0207848 3182. Email: david.squires@ kcl.ac.uk.

\section{Deputy Editor}

Gráinne Conole, Institute for Learning and Research Technology, University of Bristol, 8-10 Berkeley Square, Bristol BS8 1HH. Phone: 0117928 7087. Fax: 0117928 7112. Email: g.conole@bristol.ac.uk.

\section{Executive Editor}

Gabriel Jacobs, European Business Management School, University of Wales, Swansea SA2 8PP. Phone: 01792 295577. Fax: 01792 295626. Email: g.c.jacobs@swansea.ac.uk.

\section{Reviews Editor}

Philip Barker, Interactive Systems Research Group, School of Computing and Mathematics, University of Teesside, Middlesbrough, Cleveland TS1 3BA. Phone: 01642 342660. Fax: 01642 226822. Email: philip.barker@teesside.ac.uk.

\section{Editorial Board}

Lynne Brindley, University of Leeds

Stephen Brown, De Montfort University, Leicester

Graham Chesters, University of Hull

Betty Collis, University of Twente, Netherlands

Jonathan Darby, University of Oxford

Peter Goodyear, University of Lancaster

Nick Hammond, University of York

Roger Hartley, University of Leeds

David Jonassen, Pennsylvania State University, USA

Michael Kibby, University of Strathclyde

Ray McAleese, Heriot-Watt University

Harry McMahon, University of Ulster

Dianne Phillips, Manchester Metropolitan University

Bridget Somekh, University of Huddersfield

Robert Ward, University of Huddersfield 